\title{
Onion yield as a function of soil tillage system and soil water content
}

\author{
Jardênia R. Feitosa ${ }^{1}$, Haroldo C. Fernandes², Paulo R. Cecon², Daniel M. Leite ${ }^{1}$, \\ Filipe M. T. Nery ${ }^{1} \&$ Janielle S. Pereira ${ }^{1}$
}

\begin{abstract}
${ }^{1}$ Universidade Federal do Vale do São Francisco. Juazeiro, BA, Brasil. E-mail: jardenia.rodrigues@univasf.edu.br (Corresponding author) - ORCID: 0000-0001-6019-4941; daniel.mariano@univasf.edu.br - ORCID: 0000-0002-6174-1190; filipemtn@gmail.com - ORCID: 0000-0002-0856-2169; janielle.engenheira@gmail.com - ORCID: 0000-0002-5506-3688

${ }^{2}$ Universidade Federal de Viçosa. Viçosa, MG, Brasil. E-mail: haroldo@ufv.br - ORCID: 0000-0001-5276-5441; cecon@ufv.br - ORCID: 0000-00018213-0199
\end{abstract}

\begin{abstract}
Excessive tillage operations under inadequate conditions can raise the cost of agricultural production and lead to soil degradation without adequate crop response. The objective of this study was to evaluate the onion crop response to soil water contents and tillage systems. Three tillage systems were evaluated: P1 (plowing + two harrowings + two seedbed raising operations), P2 (two harrowings + one seedbed raising operation), P3 (one harrowing + one seedbed raising operation); and four soil water contents: 12, 15, 23 and $26 \%$. The experiment was conducted in the irrigated perimeter of Tourão, Juazeiro, BA, Brazil ( $9^{\circ} 24^{\prime} 7.3^{\prime \prime} \mathrm{S}$; $40^{\circ} 26^{\prime} 8.7^{\prime \prime} \mathrm{W}$ and altitude of $368 \mathrm{~m}$ ), in 2017, and was installed in split plots, in a randomized block design, with four repetitions. Water contents were arranged in the plots and tillage systems in the subplots. Crop response to the applied treatments was evaluated through the determination of the emergence speed index of the seedlings, regularity of the longitudinal distribution of seedlings, final stand, total and marketable yields of the crop and yield per bulb transverse diameter class. The variation of soil water content had a quadratic effect on the variables emergence speed index, final stand and total onion yield. The treatments did not significantly affect the longitudinal distribution of plants and marketable yield. The tillage system composed of one harrowing and one seedbed raising operation showed to be the most appropriate for onion cultivation by direct seeding.
\end{abstract}

Key words: horticulture, seeding, agricultural mechanization

\section{Produtividade da cebola em função do sistema de preparo e teor de água do solo}

\begin{abstract}
RESUMO: O excesso de operações mecanizadas de preparo do solo em condições inadequadas pode elevar o custo da produção agrícola e ocasionar a degradação do solo, sem que sejam obtidas respostas adequadas da cultura. Objetivou-se com este trabalho avaliar a resposta da cultura da cebola em função de teores de água e sistemas de preparo do solo. Foram avaliados três sistemas de preparo: P1 (aração, duas gradagens e duas operações de encanteiramento); P2 (duas gradagens e uma operação de encanteiramento); P3 (uma gradagem e uma operação de encanteiramento); e quatro teores de água do solo, 12, 15, 23 e 26\%. O experimento foi conduzido no perímetro irrigado Tourão, Juazeiro, BA ( $9^{\circ} 24^{\prime} 7.3^{\prime \prime}$ S; $40^{\circ} 26^{\prime} 8.7^{\prime \prime}$ W e altitude de $368 \mathrm{~m}$ ), em 2017, sendo instalado em parcelas subdivididas, no delineamento em blocos casualizados, com quatro repetições. Nas parcelas foram dispostos os teores de água e nas subparcelas, os sistemas de preparo. A resposta da cultura aos tratamentos foi avaliada por meio da determinação do índice de velocidade de emergência das plântulas, regularidade da distribuição longitudinal das plântulas, estande final, produtividade total, comercial da cultura e produtividade por classe de diâmetro transversal dos bulbos. A variação do teor de água no solo apresentou efeito quadrático sobre as variáveis velocidade de emergência, estande final e produtividade total de cebola. Os tratamentos não afetaram significativamente a distribuição longitudinal das plântulas e a produtividade comercial. O sistema de preparo composto por uma gradagem e uma operação de encanteiramento se mostrou o mais adequado ao cultivo da cebola por semeadura direta.
\end{abstract}

Palavras-chave: olericultura, semeadura, mecanização agrícola 


\section{INTRODUCTION}

Soil tillage may interfere with characteristics that determine the commercial quality of onion (Allium cepa L.), such as shape, size and health of the bulbs.

Onion cultivation by means of the conventional tillage system is characterized by excessive turning of the soil, which is subjected to plowing and subsequent breaking of aggregates with rotary hoe. These operations cause soil pulverization and, consequently, physical, chemical and biological degradation (Loss et al., 2015).

The use of reduced tillage systems is an alternative to performing this excessive number of turning operations. However, there are doubts regarding the expected yield, bulb quality, time of cultivation and production cost of onions in these systems (Factor et al., 2012).

Rós et al. (2014) stated that the main argument contrary to the use of conservation systems in vegetable cultivation is that crops whose part of commercial interest develops completely or partially below the soil surface are sensitive to compaction, inadequate aeration or poor drainage, which may result in low yield.

Distribution and adequate germination of seeds and uniformity in seedling emergence are among the biggest challenges encountered in onion planting by direct seeding (Marouelli et al., 2005; Madeira \& Oliveira, 2014; Gireesh et al., 2017). The conditions under which sowing is performed are hence decisive for successful cultivation of this vegetable.

Therefore, the objective of this study was to evaluate the response of onion crop as a function of the initial soil water content and tillage system adopted.

\section{Material AND Methods}

The experiment was conducted in the irrigated perimeter of Tourão, municipality of Juazeiro, BA, Brazil ( $9^{\circ} 24^{\prime} 7.3^{\prime \prime} \mathrm{S}$; $40^{\circ} 26^{\prime} 8.7^{\prime \prime} \mathrm{W}$ and altitude of $368 \mathrm{~m}$ ), from June to October 2017. The soil of the site was classified as Vertisol of clay loam texture, with mean density of $1.26 \mathrm{Mg} \mathrm{m}^{-3}$ and mean water content at field capacity of $19.96 \mathrm{dag} \mathrm{kg}^{-1}$.

A split-plot scheme was used, and the treatments were four initial soil water contents, arranged in the plots, and three soil tillage systems, arranged in the subplots. A randomized block design with four repetitions was adopted, and each experimental unit corresponded to a seedbed with top width of $1.25 \mathrm{~m}$ and length of $20 \mathrm{~m}$.

The soil tillage systems evaluated were composed of P1 (one plowing, two harrowings and two seedbed raising operations); P2 (two harrowings and one seedbed raising operation) and P3 (one harrowing and one seedbed raising operation).

These systems were defined by taking as reference the most used form of tillage by the onion producers of the São Francisco Valley (plowing, two harrowings and one or two seedbed raising operations). In all cases, tillage operations were followed by sowing of the crop.

Four soil water content were evaluated $(12,15,23$ and $26 \%$ ), obtained with the application of water depths on soil surface before the tillage and planting operations, using a micro-sprinkler irrigation system. Soil wetting was monitored using the electronic moisture meter, HidroFarm brand, HFM2130 model, determining the water content at one point in the central region of each subplot, with three readings at each point, as recommended by the manufacturer for point measurements. The arithmetic mean of the values determined in each plot was used to calculate the water depth required to raise the soil water content to the desired level and the time required to apply it, considering a wetting depth of $0.30 \mathrm{~m}$.

Soil tillage was performed using a Valtra tractor, BM 110 model, 4 x 2 with auxiliary front-wheel drive (AFWD) and nominal power of $116 \mathrm{hp}(85 \mathrm{~kW})$ at engine rotation of 2300 rpm; a fixed plow, Tatu Marchesan brand, AF model, with three discs of 26 " x $4.75 \mathrm{~mm}$ and theoretical cutting width of 0.92 m; an off-set harrow, KLR' brand, GACI245 model, with 14 discs of 24 ", spaced by $0.254 \mathrm{~m}$ and theoretical working width of $1.75 \mathrm{~m}$; a rotary hoe equipped with seedbed raiser, Mec-Rul brand, ERP 150 model, theoretical cutting width of $1.50 \mathrm{~m}$ and seedbed width of $1.25 \mathrm{~m}$, working with the impact plate fully lowered; and a pneumatic precision seeder, Jumil brand, Natura Air 2400 model, usable width of 1.64 m, five planting rows, minimum spacing between rows (double row) of $0.10 \mathrm{~m}$.

The seeder's pneumatic meter was equipped with smooth vertical discs, with 120 holes of $0.01 \mathrm{~m}$ in diameter, for sowing the onion in double row. The seeder was regulated to place twenty seeds per linear meter, at depth of $0.012 \mathrm{~m}$, with spacing of $0.10 \mathrm{~m}$ between single rows and $0.15 \mathrm{~m}$ between double rows. The negative pressure of the metering mechanism, measured by a vacuum meter installed in the seeder, was kept at 50 mbar. The displacement speed during the operation was $0.77 \mathrm{~km} \mathrm{~h}^{-1}$.

Planting was carried out using seeds of the onion variety NUN 1205, characterized by being a hybrid onion, of short days and super early. Sowing performed at the end of June 2017, and the beginning of emergence was observed six days after it. The bulbs were harvested on October 6, 2017, 100 days after sowing, when more than $90 \%$ of the plants had undergone natural lodging of the aerial part, a process known in Portuguese as 'estalo', Brazil. The same cultural practices were applied to all experimental units.

The crop was irrigated using a drip irrigation system, applying the water depth required to maintain the soil water content close to field capacity (19.9\%), in the layer from 0 to $0.20 \mathrm{~m}$. The required water depth was determined from the measurement of soil water content at four points per block, in the central seedbed of each plot.

Basal fertilization was broadcast, and the fertilizer was incorporated into the soil during the last operation of seedbed raising. Top dressing fertilization was performed via fertigation. When needed, insecticides and fungicides were applied in order to control pests and diseases, using a manual backpack sprayer. Weeds were controlled by herbicide application and manual weeding. Fertilizers and pesticides were applied following the agronomic recommendations for each stage of the crop.

Crop response to the treatments was evaluated based on the following variables: seedling emergence speed index, longitudinal distribution of seedlings, final stand, total bulb 
yield, yield per bulb transverse diameter class, marketable yield and mean bulb diameter.

Emergence speed index was calculated by counting the seedlings in three planting rows, in the ten central meters of each subplot. The counting began on the first day of emergence and was interrupted after stabilization. The emergence speed index was determined as proposed by Maguire (1962).

To evaluate the longitudinal distribution of seedlings, 250 longitudinal spacings were determined in one planting row of each subplot. The measured spacings $\left(\mathrm{X}_{\mathrm{i}}\right)$ were distributed in frequency classes and classified according to reference spacing $\left(\mathrm{X}_{\mathrm{ref}}=0.5 \mathrm{~m}\right)$ as double $\left(\mathrm{X}_{\mathrm{i}} \leq 0.5 \mathrm{X}_{\mathrm{ref}}\right)$, normal $\left(0.5 \mathrm{X}_{\mathrm{ref}}<\mathrm{X}_{\mathrm{i}} \leq\right.$ $\left.1.5 \mathrm{X}_{\mathrm{ref}}\right)$, or gap $\left(\mathrm{X}_{\mathrm{i}}>1.5 \mathrm{X}_{\mathrm{ref}}\right)(\mathrm{ISO}, 1982)$.

For yield determination, all plants present in an area of two square meters, located in the ten central meters of each seedbed, were harvested. The harvested plants dried in the sun for four days and, after this period, the bulbs were cleaned and weighed. The final stand of the crop was determined by counting the bulbs harvested in each seedbed. The resulting value was extrapolated to the number of plants per hectare.

The produced onion was classified according to the largest transverse diameter of the bulbs $\left(D_{t}\right)$ into seven classes: 0 $\left(\mathrm{D}_{\mathrm{t}}<15 \mathrm{~mm}\right) ; 1\left(15 \mathrm{~mm} \leq \mathrm{D}_{\mathrm{t}}<35 \mathrm{~mm}\right) ; 2\left(15 \mathrm{~mm} \leq \mathrm{D}_{\mathrm{t}}<\right.$ $50 \mathrm{~mm}) ; 3\left(50 \mathrm{~mm} \leq \mathrm{D}_{\mathrm{t}}<60 \mathrm{~mm}\right) ; 3$ full $\left(60 \mathrm{~mm} \leq \mathrm{D}_{\mathrm{t}}<70\right.$ $\mathrm{mm}) ; 4\left(70 \mathrm{~mm} \leq \mathrm{D}_{\mathrm{t}}<90 \mathrm{~mm}\right)$; and $5\left(\mathrm{D}_{\mathrm{t}} \geq 90 \mathrm{~mm}\right)$ (Brasil, 1995; CEAGESP, 2001). After classification, the bulbs of each class were weighed to determine the yield by class. Then, the percentage represented by the yield of each class in relation to the total yield was calculated.

Marketable yield was determined from the mass of bulbs with transverse diameter equal to or greater than $35 \mathrm{~mm}$. Mean bulb diameter was determined by the quotient between the sum of the values of bulb diameter and number of bulbs harvested in each seedbed.

The data obtained for the different variables were subjected to analysis of variance and regression. For the qualitative factor, the means were compared by Tukey test at $\mathrm{p} \leq 0.05$. For the quantitative factor, regression analysis was applied, and the models were selected based on the behavior of the phenomenon, coefficient of determination and significance of the regression coefficients, using Student's t-test at $\mathrm{p} \leq 0.05$.

The degree of relationship between some of the variables of interest was determined by calculating the Pearson's linear correlation coefficient, whose significance was tested at $\mathrm{p} \leq 0.05$ by the Student's t-test. All analyses were performed using the computer program R.

\section{Results AND Discussion}

The tillage system consisting of one plowing, two harrowings and two seedbed raising operations (P1) promoted higher emergence speed compared to the tillage with fewer operations (one harrowing and one seedbed raising operation - P3) (Table 1).

The greater number of mobilizations performed in P1 caused the soil to become more disaggregated, which probably increased its contact with the seeds, facilitating the absorption
Table 1. Emergence speed index (ESI) of NUN 1205 onion seedlings as a function of soil tillage systems

\begin{tabular}{cl}
\hline Tillage systems & \multicolumn{1}{c}{ ESI } \\
P1 & $25.95 \mathrm{a}$ \\
P2 & $24.71 \mathrm{ab}$ \\
P3 & $23.10 \mathrm{~b}$ \\
\hline
\end{tabular}

Means followed by the same letter do not differ by Tukey test at $\mathrm{p} \leq 0.1$

P1 - plowing + two harrowings + two seedbed raising operations; P2 - two harrowings + one seedbed raising operation; P3 - one harrowing + one seedbed raising operation

of water and nutrients and, consequently, accelerating germination and allowing a good development of the primary root (Hawary et al., 2017).

The variation in the initial soil water content caused a quadratic effect on the emergence speed index (ESI) (Figure 1).

The ESI increased with the increment in soil water content, reaching a maximum value of 30.15 for a corresponding water content of $19.72 \%$. Such response is probably associated with the process of seed imbibition, which affects germination and seedling emergence due to both the lack and excess of water (Peske \& Peske, 2011).

According to Peske \& Peske (2011), the transfer of water from the soil to the seeds is necessary to reactivate and synthesize enzymes that act in the release of reserve substances essential for embryo growth, and the rate at which this transfer occurs is determined by the difference in the water potential between the seed and the soil. Thus, the seeds that were deposited in seedbeds with lower initial water content (12\%) probably failed to absorb enough water in the first hours after sowing in order to trigger the germination process, consequently emerging later.

The result observed in this study is consistent with the statement made by Marouelli et al. (2005) that onion sowing in soil with moisture content below $80 \%$ of field capacity, followed by irrigation, tends to generate problems of stand and uneven growth of plants, so the soil should be irrigated previously, regardless of the planting system.

It is also aligned with the assertion made by Hawary et al. (2017), that a desirable seeding bed for planting onions requires pre-irrigation in most soils, which should be kept moist until the seedlings emerge, because the drying in establishment phase reduces uniformity in crop development.

The evaluated factors did not significantly affect the longitudinal distribution of the plants. The mean spacing

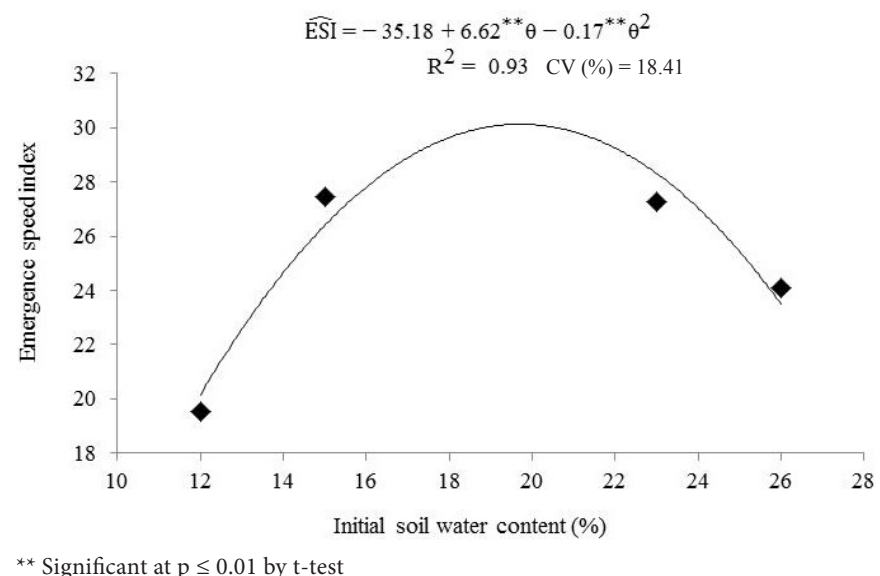

Figure 1. Emergence speed index (ESI) of onion seedlings as a function of the initial soil water content $(\theta)$ 
between plants was $0.041 \mathrm{~m}$, smaller than that used as a reference at planting. The percentages of double, normal and gap spacings were respectively $39.52,47.81$ and $12.68 \%$.

The high percentage of double spacings $(39.52 \%)$ is related to failures in the dosage of onion seeds, more specifically to the accumulation of more than one seed per hole of the dosing disc. Another factor that may have contributed is the skidding of the seeder's drive wheels, since the rotation of wheels without a corresponding displacement of the machine causes the seeds released by more than one disc hole to fall closer than they should.

The soil water content caused a quadratic effect on the final stand of the crop, whose maximum value occurred for a water content of 19.86\% (Figure 2).

The stand of plants showed a positive linear correlation $(r=0.70)$ with the seedling emergence speed index, which was significant at $\mathrm{p} \leq 0.05$. High values of the emergence speed index for a given treatment indicate that most of the plants emerged in the first days of evaluation. Thus, the stand may have been larger in these cases, because the plants were already more developed when the crop was affected by pests and diseases that caused death.

The average stands obtained were 1,994,688, 1,853,438 and $1,825,313$ plants ha ${ }^{-1}$, respectively for the systems P1 (one plowing, two harrowing and two seedbed raising operations), P2 (two harrowings and one seedbed raising operation) and P3 (one harrowing and one seedbed raising operation), which did not differ significantly from one another and are characteristic of a cultivation with high planting density.

Oliveira et al. (2015) pointed out that the planting method by direct seeding allows obtaining large final plant populations (higher than 1 million plants per hectare) without losses of yield, since the bulbs have great capacity for spatial arrangement when at high planting densities. In addition, the hybrid varieties, as the one used in this experiment, withstand higher density due to their greater genetic uniformity (Madeira \& Oliveira, 2014).

The variation in soil water content significantly affected the total production of onions (Figure 3). According to the model obtained and within the limits studied, the maximum total yield $\left(91.32 \mathrm{tha}^{-1}\right)$ is achieved for a water content of $19.54 \%$.

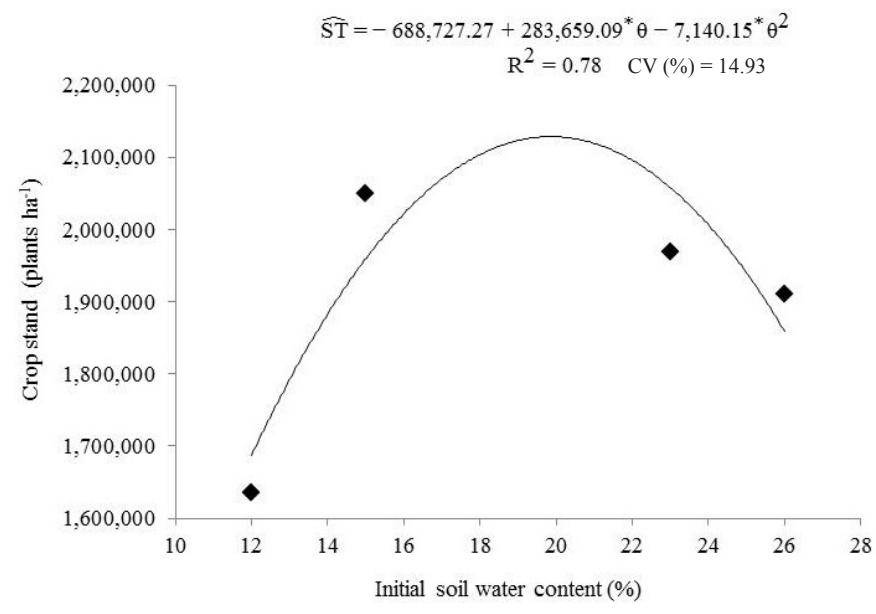

${ }^{*}$ Significant at $\mathrm{p} \leq 0.05$ by $\mathrm{t}$-test

Figure 2. Crop stand (ST) as a function of the initial soil water content $(\theta)$

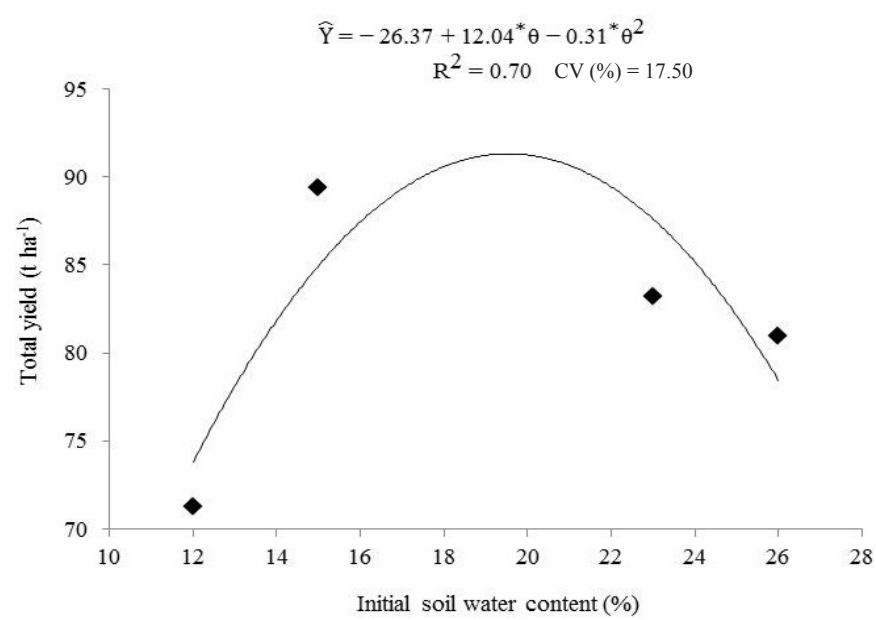

* Significant at $\mathrm{p} \leq 0.05$ by $\mathrm{t}$-test

Figure 3. Total yield of onion $(\mathrm{Y})$ as a function of the initial soil water content $(\theta)$

For the relationship between total yield and stand, there was a positive linear correlation, significant at $\mathrm{p} \leq 0.01(\mathrm{r}=$ $\left.0.57^{\star *}\right)$. These results are consistent with those of Harms et al. (2015), who evaluated the influence of onion planting density on yield and observed that the total yield increased linearly with increasing planting density.

The soil tillage systems had no significant effect on total yield. The mean values were $81.83,78.18$ and $83.59 \mathrm{t} \mathrm{ha}^{-1}$ for the systems P1 (one plowing, two harrowings and two seedbed raising operations), P2 (two harrowings and one seedbed raising operation) and P3 (one harrowing and one seedbed raising operation), respectively.

The lack of influence of soil tillage systems indicates that the use of systems with lower number of soil turning operations is an alternative to optimize onion production, reducing the cost of mechanized operations without losses of yield.

Evaluating the effect of soil tillage system on onion yield in two years of soybean-onion sequence cultivation, Benke et al. (2017) observed that the tillage practices influenced this parameter only in the first year of cultivation, with the highest yield obtained for conventional tillage (one plowing and two harrowings), when compared to the minimum tillage (one pass with rotary hoe). According to these authors, besides not having significantly influenced onion yield in the second year, the use of only one tillage operation (minimum tillage), to the detriment of conventional tillage, reduced soil erosion and nitrate leaching, increased soil organic matter and improved soil structure.

The mean values of yield achieved for each tillage system, as well as the overall mean yield of the cultivation $\left(81.20 \mathrm{t} \mathrm{ha}^{-1}\right)$, were higher than the average national yield for the 2017 season $\left(29.64 \mathrm{tha}^{-1}\right)$, as well as the average yield of the Northeast region (28.01 $\left.\mathrm{t} \mathrm{ha}^{-1}\right)$ (IBGE, 2017).

The results found in this study were similar to those of Costa et al. (2016), who obtained a total yield of $85.60 \mathrm{t} \mathrm{ha}^{-1}$, for the hybrid onion NUN 1205 cultivated in the transplant system from July to November 2014, in Petrolina, PE, Brazil.

The evaluated factors did not significantly affect the marketable yield of onion, which refer to bulbs with transverse diameter equal to or greater than $35 \mathrm{~mm}$. On average, 70.60 $\mathrm{t} \mathrm{ha} \mathrm{a}^{-1}$ of marketable onion bulbs were produced. The nonmarketable yield (bulbs with diameter smaller than $35 \mathrm{~mm}$ ) 
varied according to the soil water content (Figure 4), with maximum point at water content of $19.80 \%$. For the tillage systems P1, P2 and P3, the non-marketable yields were 12.20, 10.32 and $9.27 \mathrm{t} \mathrm{ha}^{-1}$, respectively.

The response obtained for non-marketable yield as a function of the variation in soil water content was similar to those obtained for crop stand and total yield, suggesting that the increase in the number of plants per hectare led to an increase in total yield, but also in the formation of bulbs of smaller diameter.

This finding is consistent with the results obtained by Henriques et al. (2014), evaluating the production of two onion cultivars at different planting densities. These authors observed that the increase in planting density caused an increasing linear effect on the non-marketable yield and a quadratic effect on the total and marketable yields.

Similarly, Yuri et al. (2018) found that with the increase in the spacing between plants and, consequently, the reduction in population density, there was a reduction in the yield of non-marketable bulbs for different onion cultivars.

The classification of the bulbs by transverse diameter class showed that the yields corresponding to bulbs in class 1, 2, 3 and 4 were not significantly affected by the treatments studied. These classes corresponded respectively to $13.37,54.88,26.21$ and $0.15 \%$ of total yield. Bulbs belonging to the class 5 were not produced.

The percentages of bulbs of the classes 0 and 3 full varied significantly as a function of soil tillage (Table 2). The system P3 (one harrowing and one seedbed raising operation) was the one that produced the smallest mass of bulbs in the class 0 per hectare cultivated, which is a desirable condition, since these

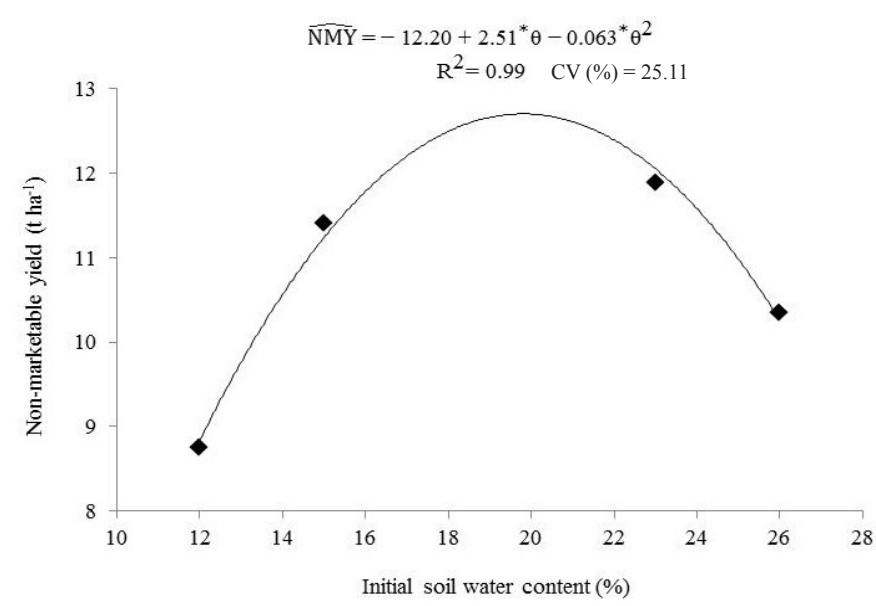

* Significant at $\mathrm{p} \leq 0.05$ by t-test

Figure 4. Non-marketable yield of onion (NMY) as a function of the initial soil water content $(\theta)$

Table 2. Relationship between the yield obtained for the classes 0 and 3 full and the total yield of onion and the mean diameter of the bulbs $(\mathrm{Dm})$ in the different soil tillage systems

\begin{tabular}{cccc}
\hline Tillage & Yield of the class in relation to the total $(\%)$ & \multirow{2}{*}{$\mathbf{D}_{\mathbf{m}}$} \\
\cline { 2 - 3 } systems & Class $\mathbf{0}$ & Class 3 full & $(\mathbf{m m})$ \\
\cline { 2 - 3 } P1 & $0.09 \mathrm{a}$ & $3.45 \mathrm{~b}$ & $40.58 \mathrm{ab}$ \\
P2 & $0.09 \mathrm{a}$ & $4.89 \mathrm{ab}$ & $39.11 \mathrm{~b}$ \\
P3 & $0.03 \mathrm{~b}$ & $7.62 \mathrm{a}$ & $44.82 \mathrm{a}$ \\
\hline
\end{tabular}

Means followed by the same letter in the column do not differ by Tukey test at $\mathrm{p} \leq 0.05$

P1 - plowing + two harrowings + two seedbed raising operations; P2 - two harrowings

+ one seedbed raising operation; P3 - one harrowing + one seedbed raising operation bulbs do not have commercial value. The systems P1 and P2, with greater number of soil mobilizations, did not differ from each other and led to higher values compared to P3.

The highest percentage of bulbs in the class 3 full per hectare cultivated occurred in the tillage system $\mathrm{P} 3$, indicating that the lowest number of soil turning operations did not limit the development of onions with larger diameter and contradicting the justification given by the producers for the excessive disaggregation of the soil, since the tillage system P1 consisting of one plowing, two harrowings and two seedbed raising operations, was the one which led to lowest yield of bulbs in this class.

Since only the classes 0 and 3 full were significantly affected by the soil tillage systems and that the tillage system $\mathrm{P} 3$ resulted in the lowest values of yield for bulbs in the class 0 and highest values for bulbs in the class 3 full, it is possible to consider conducting one harrowing and one seedbed raising operation as adequate for the commercial cultivation of onion, thus allowing the reduction of the time spent with the soil tillage operations and their costs.

The average diameter of the bulbs was significantly influenced only by the soil tillage systems, with the highest value obtained in the system P3 and the lowest value in P2 (Table 2).

All the mean values of diameter presented in Table 2 are within the range corresponding to class $2\left(35 \mathrm{~mm} \leq \mathrm{D}_{\mathrm{t}}<\right.$ $50 \mathrm{~mm}$ ), hence confirming that this was the most relevant class. Changes in consumption patterns, motivated mainly by the reduction in the number of people per family and by the concern with food waste, have been opening space in the market for onion bulbs belonging to this class.

The production of larger bulbs is directly related to increased yield and profitability of cultivation (Kurtz et al., 2012). According to Costa et al. (2016), bulbs with diameter between 50 and $70 \mathrm{~mm}$, in classes 3 and 3 full, are the most commercially valued, being preferred by the consumers in general. Bulbs produced in the system P3 were the ones closest to these classes, indicating that this tillage system was favorable for their growth.

\section{Conclusions}

1. The variation in the initial soil water content significantly influenced the onion crop response. Soil water content between 19 and 20\% maximized the emergence speed index, final stand of the crop and consequently its total yield.

2. Reduction in the number of tillage operations did not affect onion yield or the quality of the bulbs produced, in terms of their size.

3. The tillage system consisting of one harrowing and one seedbed raising operation (P3) proved to be the most adequate for onion cultivation.

\section{Literature Cited}

Benke, P. S.; Solanke, A. V.; Danawale, N. J.; Pawar, P. B. Effect of tillage and integrated weed management on weed dry weight, weed index and economics of soybean-onion sequence. Contemporary Research in India, v.7, p.41-48, 2017. 
Brasil. Ministério da Agricultura, Pecuária e Abastecimento. Portaria n. 529 de 18 agosto de 1995. Brasília: Diário Oficial da República Federativa do Brasil, 1995. p.13513. Seção 1

CEAGESP - Companhia de Entrepostos e Armazéns Gerais de São Paulo. Classificação da cebola (Allium cepa L.). São Paulo: CEAGESP, 2001. 2p.

Costa, N. D.; Resende, G. M.; Yuri, J. E. Cebola: Escolha adequada. Cultivar Hortaliças e Frutas, v.14, p.6-8, 2016.

Factor, T. L.; Silveira, J. M. C.; Purquerio, L. F. V.; Calori, A. H.; Ronchi, R. S. M.; Lima Júnior, S. Produção de cebola em função do sistema de cultivo e método de estabelecimento de plantas. Horticultura Brasileira, v.20, p.3354-3359, 2012.

Gireesh, B.; Sujatha, G.; Sunitha, B.; Rajkiran, B.; Ramana, M. V. Modification and performance evaluation of animal drawn onion seeder. International Journal of Current Microbiology and Applied Sciences, v.6, p.2749-2763, 2017. https://doi.org/10.20546/ ijcmas.2017.610.323

Harms, M. G.; Pria, M. D.; Rezende, B. L. A.; Prestes, A. M. C.; Dalazoana, F. Influência da densidade de plantas e do uso de fungicida nas doenças foliares e na produtividade de cebola. Horticultura Brasileira, v.33, p.203-207, 2015. https://doi. org/10.1590/S0102-053620150000200011

Hawary, M. Y.; Abdalla, A. S.; Elfadil, A. D.; Elkashif, M. E. Evaluation of a pneumatic precision planter performance for direct seeding of onion (Allium cepa L.) on raised beds under Gezira conditions, Sudan. Sinnar University Journal, v.5, p.143-158, 2017.

Henriques, G. P. S. A.; Granjeiro, L. C.; Paulino, R. C.; Marrocos, S. T. P.; Souza, V. F. L.; Ribeiro, R. M. P. Produção de cebola cultivada sob diferentes densidades de plantio. Revista Brasileira de Engenharia Agrícola e Ambiental, v.18, p.682-687, 2014. https:// doi.org/10.1590/S1415-43662014000700002

IBGE - Instituto Brasileiro de Geografia e Estatística. Levantamento sistemático da produção agrícola: Pesquisa mensal de previsão e acompanhamento das safras agrícolas no ano civil. Rio de Janeiro: IBGE, 2017. 82p.
ISO - International Organization for Standardization. Draft International Standard ISO/DIS 7256/1. Sowing equipments: Method of test - Part 1: Single seed drills (precision drills). 1982.

Kurtz, C.; Ernani, P. R.; Meirelles, J. L. C.; Petry, E. Rendimento e conservação de cebola alterados pela dose e parcelamento de nitrogênio em cobertura. Revista Brasileira de Ciência do Solo, v.36, p.865-875, 2012. https://doi.org/10.1590/S010006832012000300017

Loss, A.; Basso, A.; Oliveira, B. S.; Koucher, L. P.; Oliveira, R. A.; Kurtz, C.; Lovato, P. E.; Curmi, P.; Brunetto, G.; Comin, J. J. Total organic carbon and soil aggregation under a no-tillage agroecological system and conventional tillage system for onion. Revista Brasileira de Ciência do Solo, v.39, p.1212-1224, 2015. https://doi.org/10.1590/01000683rbcs20140718

Madeira, N. R.; Oliveira, V. R. Estande em cebola: Fator fundamental para o sucesso do empreendimento. Nosso Alho, v.20, p.63-66, 2014.

Maguire, J. D. Speed of germination-aid in selection and evaluation for seedling emergence and vigor. Crop Science, v.2, p.176-177, 1962. https://doi.org/10.2135/cropsci1962.0011183X000200020033x

Marouelli, W. A.; Costa, E. L.; Silva, H. R. Irrigação na cultura da cebola. Brasília: Embrapa Informação Tecnológica, 2005. 17p.

Oliveira, V. R.; Madeira, N. R.; Resende, F. V.; Souza, R. B.; Marouelli, W. A. Sistema de produção da cebola. In: Cultura da cebola: Tecnologia de produção e comercialização. Lavras: Editora UFLA, 2015. Cap.6, p.185-203.

Peske, S. T.; Peske, F. B. Absorção de água sob estresse. Seed News, v.15, p.12-15, 2011.

Rós, A. B.; Tavares Filho, J.; Barbosa, G. M. C. Produtividade de raízes tuberosas de batata-doce em diferentes sistemas de preparo do solo. Ciência Rural, v.44, p.1929-1935, 2014.

Yuri, J. E.; Resende, G. M.; Costa, N. D. Produtividade de cultivares de cebola em diferentes populações de plantas em semeadura direta. Revista Brasileira de Agricultura Irrigada, v.12, p.2716-2724, 2018. https://doi.org/10.7127/rbai.v12n300892 